\title{
Records of scythridids from Southeastern Kazakhstan, with description of five new species (Lepidoptera: Scythrididae)
}

\author{
Kari Nupponen, Urmas Jürivete \& Aleksandr Pototski
}

Nupponen, K., Jürivete, U. \& Pototski, A. 2005: Records of scythridids from Southeastern Kazakhstan, with description of five new species (Lepidoptera: Scythrididae). — Entomol. Fennica 16: 65-73.

A list of seven species, embracing 56 specimens of the family Scythrididae, from Southeastern Kazakhstan, is presented. The material was collected in mid-May, 2003. Five new species are described: Scythris hostilis K. Nupponen sp. n., S. ianitella K. Nupponen sp. n., S. ingens K. Nupponen sp. n., S. juerivetei K. Nupponen sp. n. and S. pototskii K. Nupponen sp. n.. One additional species is reported as new for Kazakhstan and one species as new for Kirgisia. The known distribution range of each species is given.

\section{K. Nupponen, Miniatontie 1 B 9, FI-02360 Espoo, Finland \\ U. Jürivete, Moora Umb 8, EE-11625 Tallinn, Estonia \\ A. Pototski, Liimi 1, EE-10621 Tallinn, Estonia}

Received 12 January 2004, accepted 31 August 2004

\section{Introduction}

The scythridid fauna of Central Asia is poorly known. The material from that region is scarce in collections, and only a few records have been published during the last decades (Falkovitch 1969, 1972, 1979, 1986, Bengtsson 1997).

Recently, Estonian lepidopterists explored southeastern Kazakhstan and collected a rich material of Microlepidoptera, including some scythridids. The scythridids were kindly loaned to the senior author for examination, and his studies revealed that five of the seven recorded taxa were previously unknown and the remaining one was recorded from Central Asia for the first time. The descriptions of new species, and the list of all recorded scythridids are presented below.

For each species, the known distribution is also given.

\section{The collecting sites, material and methods}

The material, altogether 56 specimens of scythridids, was collected during 13-20.V.2003. The collecting sites are located at the northern foothills of the Kungei Alatau Mountains in the vicinity of the River Charyn (Figs. 1-2). The majority of scythridid specimens were collected by sweeping in the afternoon. A few specimens came to artificial light at night. The material is generally deposited in the collections of the authors. The species are presented in alphabetic order, as the family Scythrididae has not been revised, and the relationships within the family are not fully understood.

\section{List of scythridid species}

Scythris clavella (Zeller, 1855)

SE-Kazakhstan, $43^{\circ} 17-18^{\prime} \mathrm{N}$ 7858-59'E, 


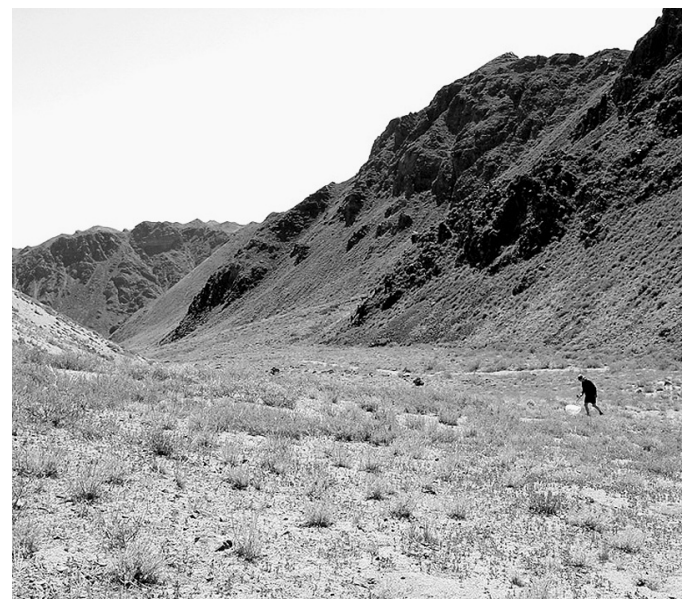

Fig. 1. Dry valley in Charyn (1,100 m a.s.I.) with steep, rocky steppe slopes on both sides. Habitat of Scythris hostilis K. Nupponen sp. n., S. ianitella K. Nupponen sp. n., S. ingens K. Nupponen sp. n., and S. juerivetei K. Nupponen sp. $n$.

Alma-Ata $180 \mathrm{~km}$ E, Charyn River, 1,000 m a.s.1., 1 त 13-20.V.2003, leg. U. Jürivete \& A. Pototski.

SE-Kazakhstan, $43^{\circ} 44^{\prime} \mathrm{N} 77^{\circ} 01^{\prime} \mathrm{E}$, AlmaAta $70 \mathrm{~km} \mathrm{~N}$, Zarechje village near Kapchagay lake, 500-530 m a.s.1., 2 ๙ึ̄ 21.V.2003, leg. U. Jürivete \& A. Pototski.

Distribution. C and S Europe east to SW Altai, N Kazakhstan, Dzhungarian Alatau.

Remarks. S. clavella has been reported from North Kazakhstan and the Dzhungarian Alatau Mountains (Sinev 1993), but without exact data. Additionally, the taxon has been recorded from Kirgisia (1 $\widehat{\jmath}$ labelled "Kyrgyzstan, Issyk-Kul, prope pag. Kadzhy-Saj, alt. 1,650 m, lum., 29.VI.1999, E. Rutjan leg.”, K. Nupponen det. \& coll.). New to Kirgisia.

Scythris hostilis K. Nupponen, sp. n.

Type material. Holotype: $\sigma^{\top}$ (Fig. 3a): SE-

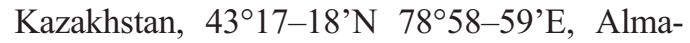
Ata 180 km E, Charyn River, 1,000 m a.s.l., 1619.V.2003, leg. U. Jürivete \& A. Pototski. Genitalia slide: K. Nupponen prep. no. 2/07.IX.2003. In coll. Nupponen. Paratypes (2 $\widehat{\partial} \hat{\sigma}, 3$ 우): Same data as holotype except for dates: 2 ๙저 3 우 우 1619.V.2003, 1 กै 13-20.V.2003. Genitalia slide: K. Nupponen prep. no. 1/07.IX.2003 (q). In colls. Nupponen, Jürivete and Pototski.

Diagnosis. Externally $S$. hostilis sp. n. resem-

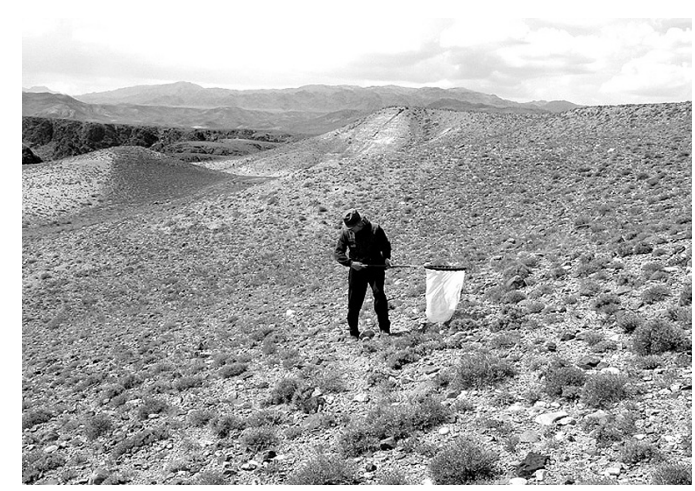

Fig. 2. Dry steppe at the edge of Charyn Canyon.

Habitat of Scythris pototskii K. Nupponen, sp. n.

bles $S$. ianitella sp. n. (see below) but the forewings lack an olive hue. Numerous species of scythridids occurring in southern deserts of Central Asia differ from $S$. hostilis by whitish ground colour of forewings (see Falkovitch 1969, 1972). The male genitalia of $S$. hostilis are easy to separate from those of the other known scythridids by a peculiar, long gnathos furnished with a circular plate, as well as by the shape of the abdominal segment VIII. In the female genitalia the sterigma is membranous and does not exhibit any distinct characteristics.

Description. Wingspan 11-12.5 mm. Head, thorax, tegula, collar and haustellum dark brown, laterally mixed with dirty white. Neck tuft whitish. Antenna dark brown, scape ventrally with long, white hairscales. Labial palp: segment I white, segments II and III dark brown mixed with dirty white. Legs dark brown, femur more and tibia and tarsus less mixed with dirty white scales. Forewing narrow, dark brown; greyish white scales frequently exist over the wing and almost covering apical $1 / 3$ of the wing; white scales in fold forming a streak from base to $2 / 3$; three indistinct blackish brown spots in fold at $0.25,0.5$ and 0.7 . Hindwing pale fuscous.

Male genitalia (Fig. 4a-b). Uncus bifurcate, laterally with triangular processes. Gnathos arm long, tapered from base to 0.75 , then curved by $90^{\circ}$; distal 1/4 semicircular, broadest at middle, apex bent and pointed; at 3/4 a less sclerotized, circular plate united to ventral side of gnathos arm. Aedeagus rather long, bent, bifurcate. Valva subtriangular, at middle slightly compressed; from 0.3 to 0.9 a longitudinal flap; apex with a 
Fig. 3. - a. Imago (holotype) of Scythris hostilis K. Nupponen, sp. $\mathrm{n}$. - b. Imago (holotype) of Scythris ianitella K. Nup-
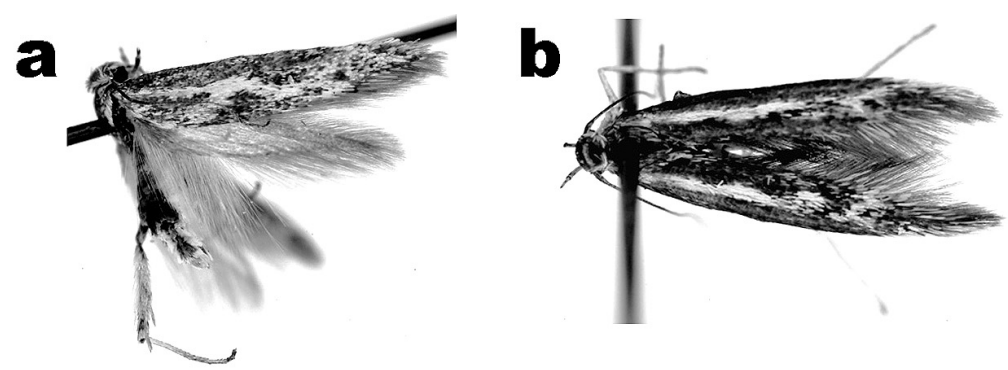
ponen, sp. n. - c. Imago (holotype) of Scythris ingens $\mathrm{K}$. Nupponen, sp. n. - d. Imago (holotype) of Scythris juerivetei K. Nupponen, sp. n. - e. Imago (holotype) of Scythris pototskii K. Nupponen, sp. n.
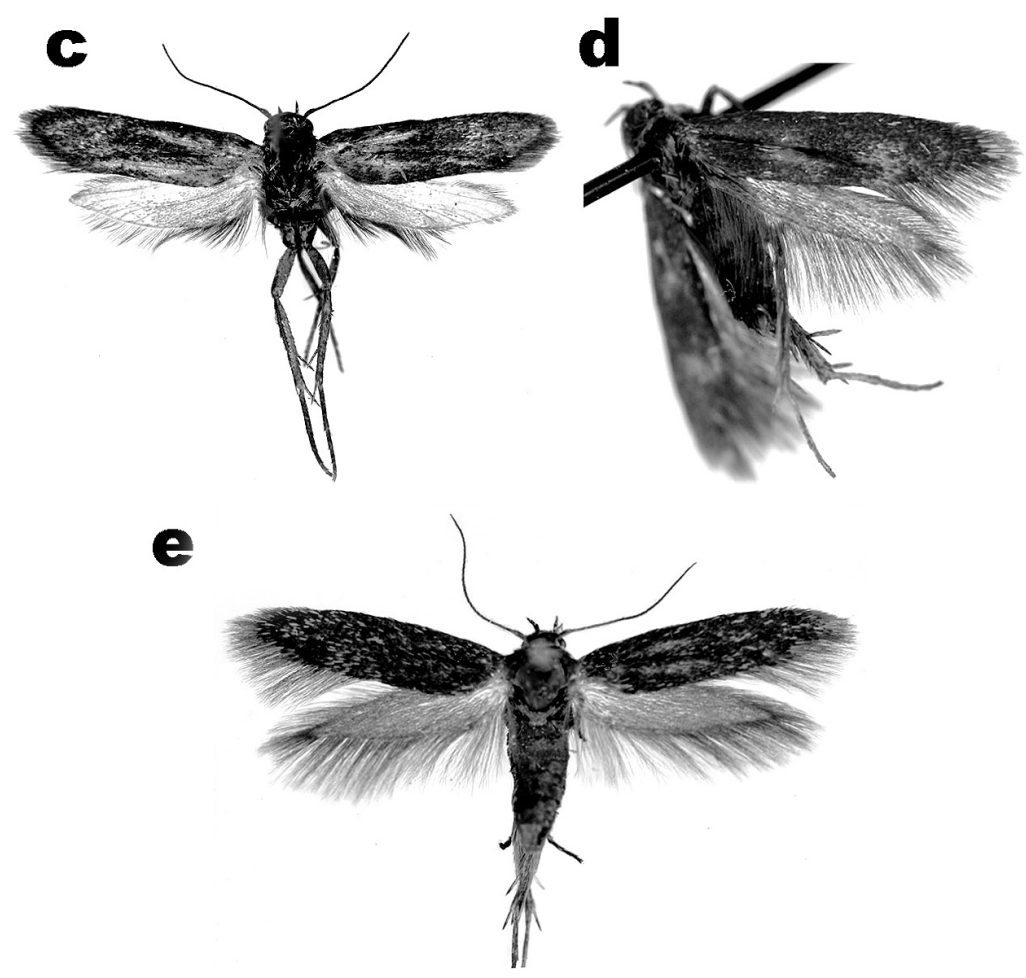

stout spine directed outwards. Tergum VIII arched, posterior $1 / 3$ broadest; laterally with an oval, strongly spinose process. Sternum VIII a broad plate; near posterior corners two semicircular flaps; posterior margin concave; anterior margin with rectangular median incision, and two pairs of processes, inner one digitate with rectangular basal flap and outer one bent and pointed.

Female genitalia (Fig. 4c). Membranous; indistinct wrinkles around ostium. Sternum VII

Fig. 4. - a. Male genitalia of Scythris hostilis (holotype). - b. Tergum VIII (left) and sternum VIII (right) of Scythris hostilis (holotype). - c. Female genitalia of Scythris hostilis (paratype).
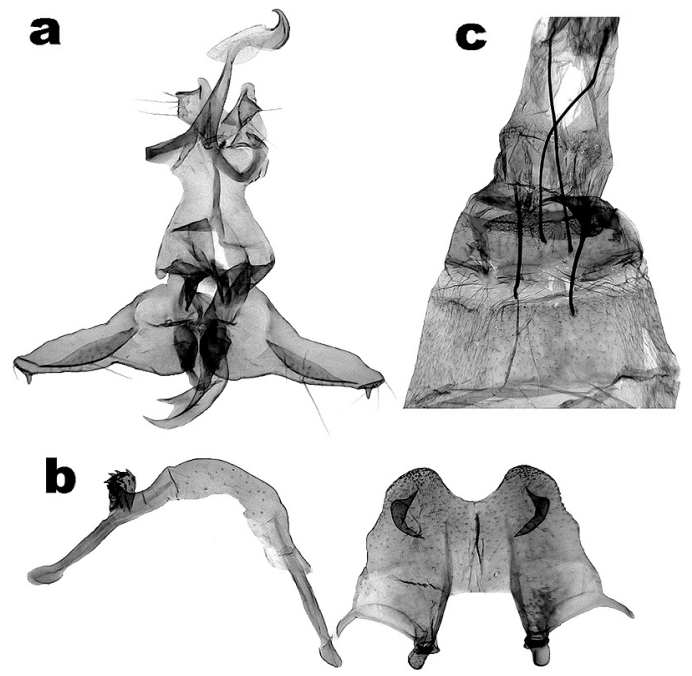
rectangular, posterior margin medially shallowly concave. Apophyses anteriores $0.5 \times$ length of apophyses posteriores.

Bionomy. The specimens were collected by artificial light at night in mid-May. The habitat is a dry valley with steep, rocky steppe slopes on both sides (Fig.1). The immature stages are unknown.

Distribution. SE Kazakhstan.

Etymology. Lat. hostilis $=$ hostile. The species name alludes to the shape of gnathos in the male genitalia, reminiscent of an attacking cobra (Naja naja).

Remarks. S. hostilis cannot be assigned to any known species group.

Scythris ianitella K. Nupponen, sp. n.

Type material. Holotype: $\widehat{\partial}$ (Fig. 3b): SE-

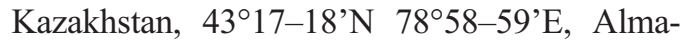
Ata 180 km E, Charyn River, 1,000 m, 1619.V.2003, leg. U. Jürivete \& A. Pototski. Genitalia slide: K. Nupponen prep. no. 3/07.IX.2003. In coll. Nupponen.

Diagnosis. Externally S. ianitella sp. n. resembles $S$. hostilis sp. n. (see above) but differs from that by an olive hue of the forewings (see also 'Diagnosis' of $S$. hostilis). In the male genitalia the strong setae of valva remind to some extent of those of S. tytrella Falkovitch, 1969 and a bifurcate aedeagus resembles that of $S$. dicroa Falkovitch, 1972. However, S. ianitella is easy to separate from those and the other known scythridids by a peculiar shape of the abdominal segment VIII.

Description. Wingspan $11.5 \mathrm{~mm}$. Head, thorax, tegula and haustellum dark brown with slight olive tinge, laterally with scattered whitish scales. Neck tuft dirty whitish. Labial palp moderately long; segment I and basal half of segment II whitish, otherwise dark brown with a few whitish scales. Antenna dark brown, scape ventrally with long, whitish hairscales. Legs brown, more or less mixed with pale scales. Abdomen dorsally fuscous, ventrally greyish white. Forewing dark brown with slight olive hue; distinct whitish streak in fold from base to cell end; subapical and apical area mixed with whitish scales, more frequently near costal margin and in tornus; two indistinct blackish brown spots in midwing at 0.6 and 0.75 . Hindwing fuscous.

Male genitalia (Fig. 5a-b). Uncus rectangular, bent, strongly sclerotized. Gnathos thick, sclerotized, slightly bent, tapered, tip pointed. Aedeagus complex, basically bottle-shaped, basally with an irregular extension, distal half bent and slightly tapered. Valva rather broad, almost straight; apex medially incised, ventrally rounded and dorsally extended triangularly; median part and ventral margin from base to apex densely covered with strong, long setae; valva basally with about five spines. Vinculum a large, subquadrangular plate with concave posterior mar-

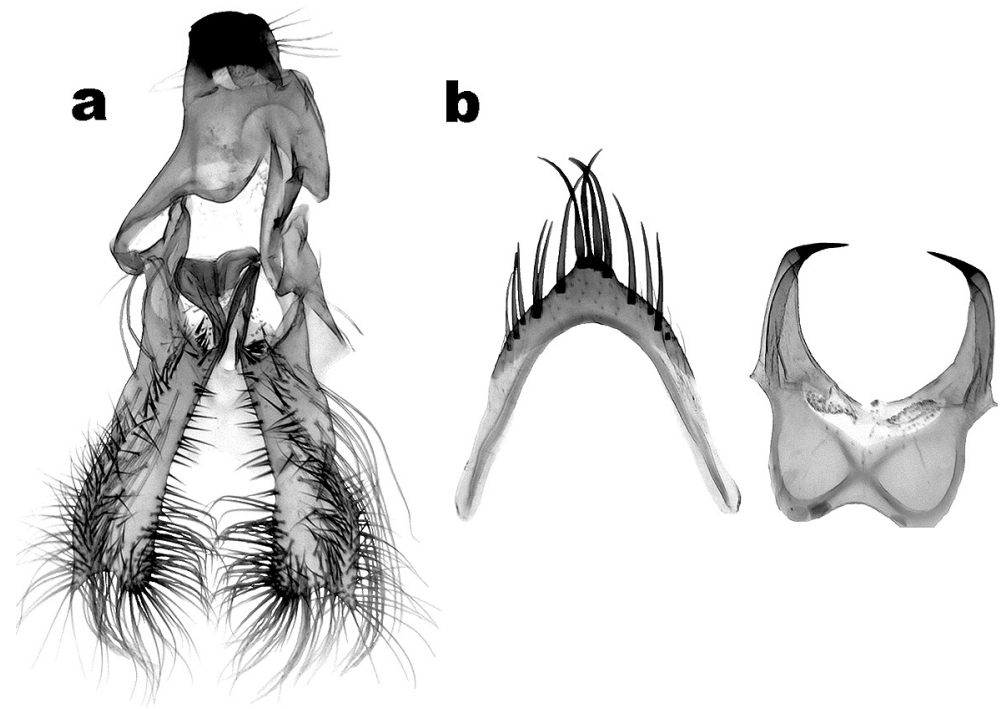

Fig. 5. - a. Male genitalia of Scythris ianitella (holotype). - b. Tergum VIII (left) and sternum VIII (right) of Scythris ianitella (holotype). 
Fig. 6. - a. Male genitalia of Scythris ingens (holotype). - b. Tergum VIII (right) and sternum VIII (left) of Scythris ingens (holotype).
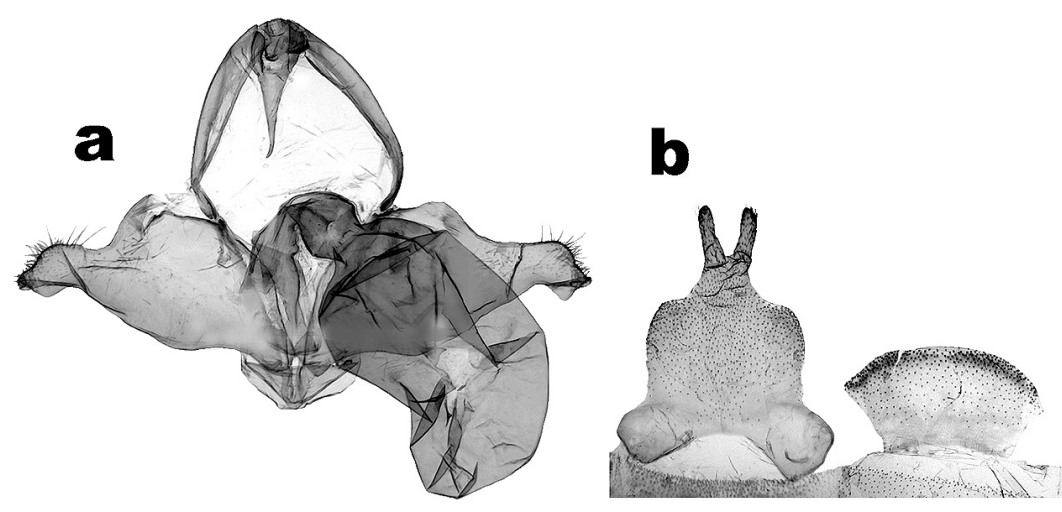

gin. Tergum VIII arched; posterior $1 / 3$ more sclerotized and distally slightly enlarged, at margin about 15 long, stout pegs. Basal part of sternum VIII rectangular with a submarginal, sclerotized belt; posterior and anterior margins concave; posterior processes robust, tapered, subapically curved by $80^{\circ}$, apex pointed and strongly sclerotized.

Female genitalia. Unknown.

Bionomy. The specimen was collected by artificial light at night. The habitat is a dry valley with steep, rocky steppe slopes on both sides (Fig.1). The immature stages are unknown.

Distribution. SE Kazakhstan.

Etymology. Lat. ianitor $=$ gatekeeper. From the abdominal segment VIII in the male genitalia, where tergum resembles a gate and sternum reminds of an open locking device.

Remarks. The structure of the male genitalia of $S$. ianitella do not indicate a relationship to any known species group.

Scythris ingens K. Nupponen, sp. n.

Type material. Holotype: $\sigma^{\lambda}$ (Fig. 3c): SEKazakhstan, 43ำ-18'N 78 58-59'E, AlmaAta $180 \mathrm{~km}$ E, Charyn River, 1,000 m a.s.1., 1320.V.2003, leg. U. Jürivete \& A. Pototski. Genitalia slide: K. Nupponen prep. no. 4/07.IX.2003. In coll. Nupponen.

Diagnosis. Externally S. ingens sp. n. resembles many dark, medium-sized scythridids, but may be separated by broad wings and partly transparent hindwings. In the male genitalia a huge aedeagus is unique and cannot be mixed with that of any other known scythridids.

Description. Wingspan $13 \mathrm{~mm}$. Head, collar, tegula, haustellum, neck tuft, antenna, thorax and legs dark brown. Labial palp dark brown mixed with pale brown scales. Abdomen dorsally fuscous, ventrally pale brown. Forewing broad, dark brown; in subapical area scattered pale fuscous scales. Hindwing broad, pale fuscous, scales rather sparse, fringe darker.

Male genitalia (Fig. 6a-b). Uncus heartshaped. Gnathos basally slightly furrowed; distal arm long, tapered, subapically bent, tip pointed. Aedeagus basally thick, more or less irregular; at $1 / 3$ enlarged to a huge, elongated, sclerotized pouch having two triangular median teeth. Valva a broad plate; basal half broad, at 0.5 abruptly tapered, apical 0.4 shaped like a dog's head; apex shallowly incised; subapical part with a triangular, longitudinal flap. Tergum VIII subpentagonal, posterior margin convex. Sternum VIII basically rectangular; anterior corners quadrangularly extended; posterior margin medially extended, bifurcate, arms thick and digitate.

Female genitalia. Unknown.

Bionomy. The specimen was collected by sweeping at daylight. The habitat is a dry valley with steep, rocky steppe slopes on both sides (Fig. 1). The immature stages are unknown.

\section{Distribution. SE Kazakhstan.}

Etymology. Lat. ingens $=$ huge. The species name alludes to a huge aedeagus in the male genitalia of the new taxon.

Remarks. The shape of broad wings of $S$. ingens equals to that of $S$. brunneofasciella K. Nupponen \& Junnilainen, 2000 and might indicate that the two species are related. However, this cannot be confirmed until a male of $S$. brunneofasciella is found. At the moment it is impossible to assign $S$. ingens to any known species group. 

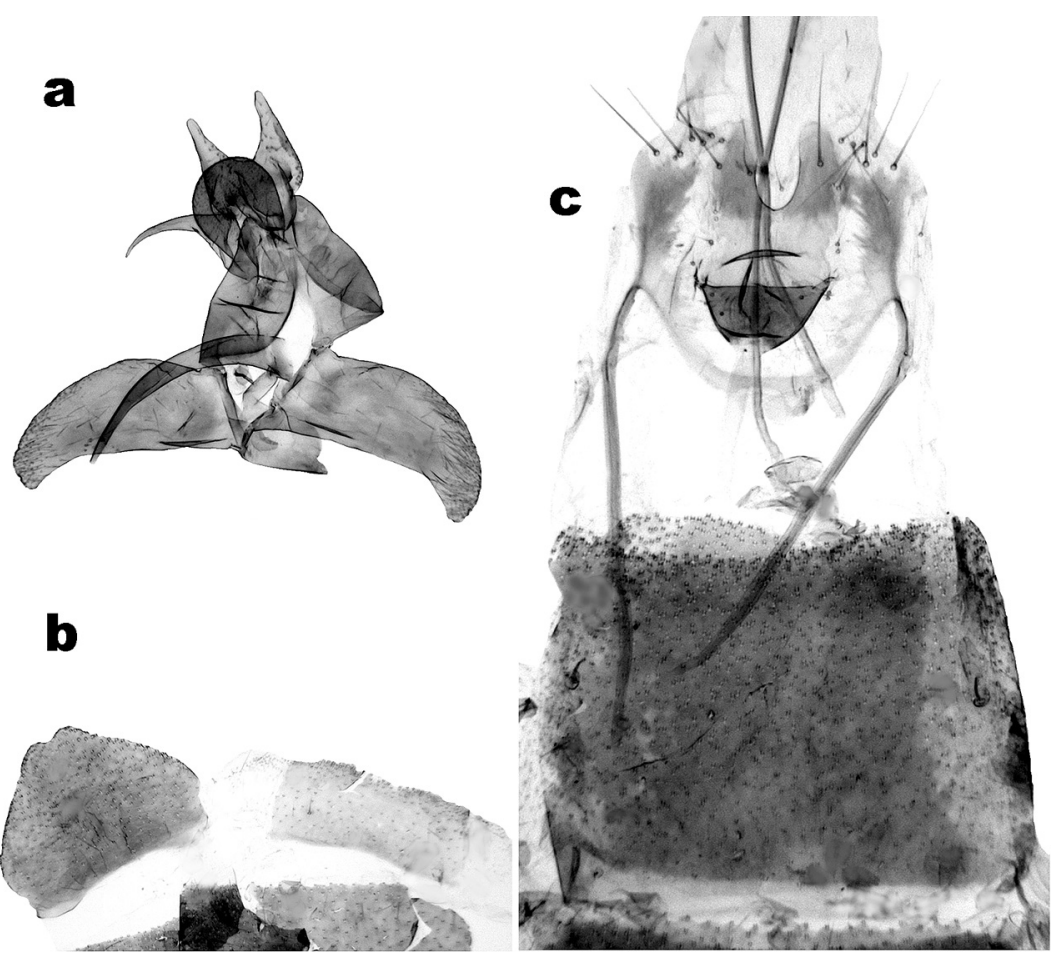

Fig. 7. - a. Male genitalia of Scythris juerivetei (paratype). - b. Tergum VIII (right) and sternum VIII (left) of Scythris juerivetei (paratype). -c. Female genitalia of Scythris juerivetei (paratype).
Scythris juerivetei K. Nupponen, sp. $\mathrm{n}$.

Type material. Holotype: $\hat{\sigma}$ (Fig. 3d): SE-

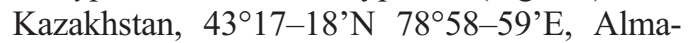
Ata $180 \mathrm{~km}$ E, Charyn River, 1,000 m a.s.1., 14.V.2003, leg. U. Jürivete \& A. Pototski. In coll. Nupponen. Paratypes (10 ̋̂̃ $\hat{\sigma}, 2$ 우): Same data

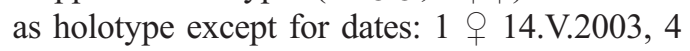

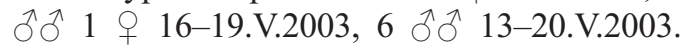
Genitalia slides: K. Nupponen prep. no. 3/01.IX.2003 (ð), 4/01.IX.2003 (†). In colls. Nupponen, Jürivete and Pototski.

Diagnosis. Externally $S$. juerivetei sp. n. resembles $S$. elenae K. Nupponen, 2000, but can be separated from that by darker and narrower forewings, a female also by absence of an oval, pale ochreous spot on the underside of hindwing. The structures of both male and female genitalia of $S$. juerivetei indicate its close relationship to $S$. elenae and S. hamardabanica K. Nupponen, 2003, but differ from those in details. In the male genitalia of $S$. juerivetei the distal incision of uncus is wider, the basal plate of gnathos round, the valva rather narrow and tapered at distal $1 / 3$ (much broader in hamardabanica, of equal width in elenae) and sternum VIII with a shallow medioposterior incision (deeply incised in ha- mardabanica, not incised in elenae). The female genitalia of $S$. juerivetei differ from those of $S$. elenae (see Remarks) and S. hamardabanica by a much larger anterior sclerotization and stout, parallel shanks of the sterigma (shanks diverging in elenae and are posterolaterally extended in hamardabanica).

Description. Wingspan 9.5-10.5 mm. Head, thorax collar, tegula and neck tuft dark brown mixed with paler scales. Haustellum pale brown. Labial palp: segment I and basal half of segment II pale brown, otherwise dark brown with a few paler scales. Legs brown, femur mixed with a few pale scales. Abdomen in male fuscous; in female ventrally and laterally pale brown, dorsally black with scattered pale scales except for pale brown segments VII and VIII. Forewing dark brown; pale brown spot in fold at $1 / 3$, and another spot of same colour at cell end reaching tornus; pale brown scales basally at dorsal margin and a rather indistinct dirty whitish dash at apex. Hindwing fuscous. Underside of wings pale fuscous in male; in female pale ochreous with scattered black scales.

Male genitalia (Fig. 7a-b). Uncus quadrangular, posterior margin with deep, U-shaped inci- 
sion. Gnathos base a round, furrowed plate; distal part basally thick, long, tapered and bent, tip pointed. Aedeagus long, bent and tapered. Valva of equal width at basal $2 / 3$; apical $1 / 3$ bent inwards and tapered, tip more or less pointed; apical $1 / 4$ setose. Tergum VIII rectangular. Sternum VIII pentagonal, distal margin shallowly incised.

Female genitalia (Fig. 7c). Sterigma stout, basically U-shaped; anterior part elongated and more sclerotized. Ostium situated at anterior margin of sterigma. Sternum VII guadrangular; posterior margin slightly concave and medially with a sclerotized oval structure. Apophyses anteriores $0.6 \times$ length of apophyses posteriores.

Bionomy. The specimens were collected by sweeping at daylight. The habitat is a dry valley with steep, rocky steppe slopes on both sides (Fig. 1). The immature stages are unknown.

Distribution. SE Kazakhstan.

Etymology. The species is dedicated to $\mathrm{Mr}$. Urmas Jürivete, an Estonian lepidopterist who collected the type series of the new taxon.

Remarks. S. juerivetei belongs to the elenae species-group (see Nupponen et al. 2000, Nupponen 2003). A female of $S$. elenae was recently discovered from the steppes of the southern Ural Mountains, and the description of female genitalia and the external appearance of the moth will be published later in a separate paper (K. Nupponen in prep.).

Scythris perlucidella K. Nupponen \& T. Nupponen, 2000

SE-Kazakhstan, $43^{\circ} 17-18^{\prime} \mathrm{N} \quad 78^{\circ} 58-59^{\prime} \mathrm{E}$, Alma-Ata $180 \mathrm{~km} \mathrm{E,} \mathrm{Charyn} \mathrm{River,} \mathrm{1,000} \mathrm{m}$ a.s.1., 7 ふふ઼ 17-18.V.2003, leg. U. Jürivete \& A. Pototski.

Distribution. Russia (S Ural, middle Volga).

Remarks. The taxon was recently described from the Southern Ural Mountains. It has also been reported from the middle Volga region as $S$. zolotuhini Sachkov, 2000 (a junior synonym of $S$. perlucidella; see Sachkov 2000, 2002). The present record extends the known distribution range of the species considerably to the east. New to Kazakhstan and Central Asia.

Scythris pototskii K. Nupponen, sp. $\mathrm{n}$.

Type material. Holotype: $\widehat{\partial}$ (Fig. 3e): SE-

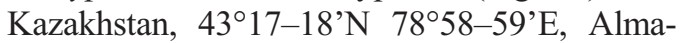

Ata $180 \mathrm{~km}$ E, Charyn River, $1,000 \mathrm{~m}$, 14.V.2003, leg. U. Jürivete \& A. Pototski. In coll.

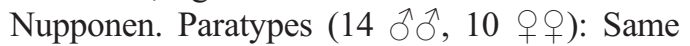

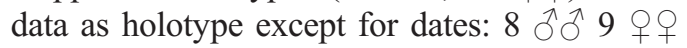
14.V.2003, 6 ठิ 1 ๆ 16-19.V.2003. Genitalia slides: K. Nupponen prep. no. 1/01.IX.2003 (ठ), 2/01.IX.2003 (ㅇ). One further genitalia preparation preserved in glycerol. In colls. Nupponen, Jürivete and Pototski.

Diagnosis. Externally $S$. pototskii sp. n. can be confused with many small, dark scythridids. According to the genitalia, the taxon is related to the subfasciata-group. The male genitalia most resemble those of $S$. spectatorella K. Nupponen, 2001, having a long, slender aedeagus and a narrow valva at distal $2 / 3$. However, $S$. pototskii is readily separated from $S$. spectatorella by a longer, S-shaped aedeagus and a bifurcate posterior margin of tergum VIII. The female genitalia remind of those of $S$. fluxilis Falkovitch, 1986, but the sterigma is broader and sternum VII quite different from that of fluxilis.

Description. Wingspan 10.5-11.5 mm. Head, thorax, tegula, collar, neck tuft and antenna dark brown. Haustellum dark brown, laterally mixed with whitish scales. Labial palp: segment I and upper surface of segment II whitish, otherwise dark brown. Legs dark brown, femur and tibia more and tarsus less mixed with whitish scales. Abdomen fuscous, ventrally in female more and in male less covered by whitish scales. Forewing dark brown; scattered white scales occur over the wing, more frequently in apical half. Hindwing fuscous.

Male genitalia (Fig. 8a-b). Uncus rectangular, posterior margin bent. Gnathos rather long; arm basally broad, tapered; apical half thin, apex bent and pointed. Aedeagus thin, $1.6 \times$ length of valva, slightly S-shaped. Basal part of valva triangular; distal 3/4 slender, digitate. Tergum VIII subtrapezoid, posterior margin more or less deeply incised. Sternum VIII subtrapezoid, posteriorly bilobed, prongs rather short, indentation widely U-shaped; anteriorly with two rather robust, tapered, converging processes and extended anterior corners.

Female genitalia (Fig. 8c). Sterigma rectangular, anterior margin widely U-shaped. Sternum VII subrectangular, posterior margin shallowly concave with U-shaped medial incision. Apo- 


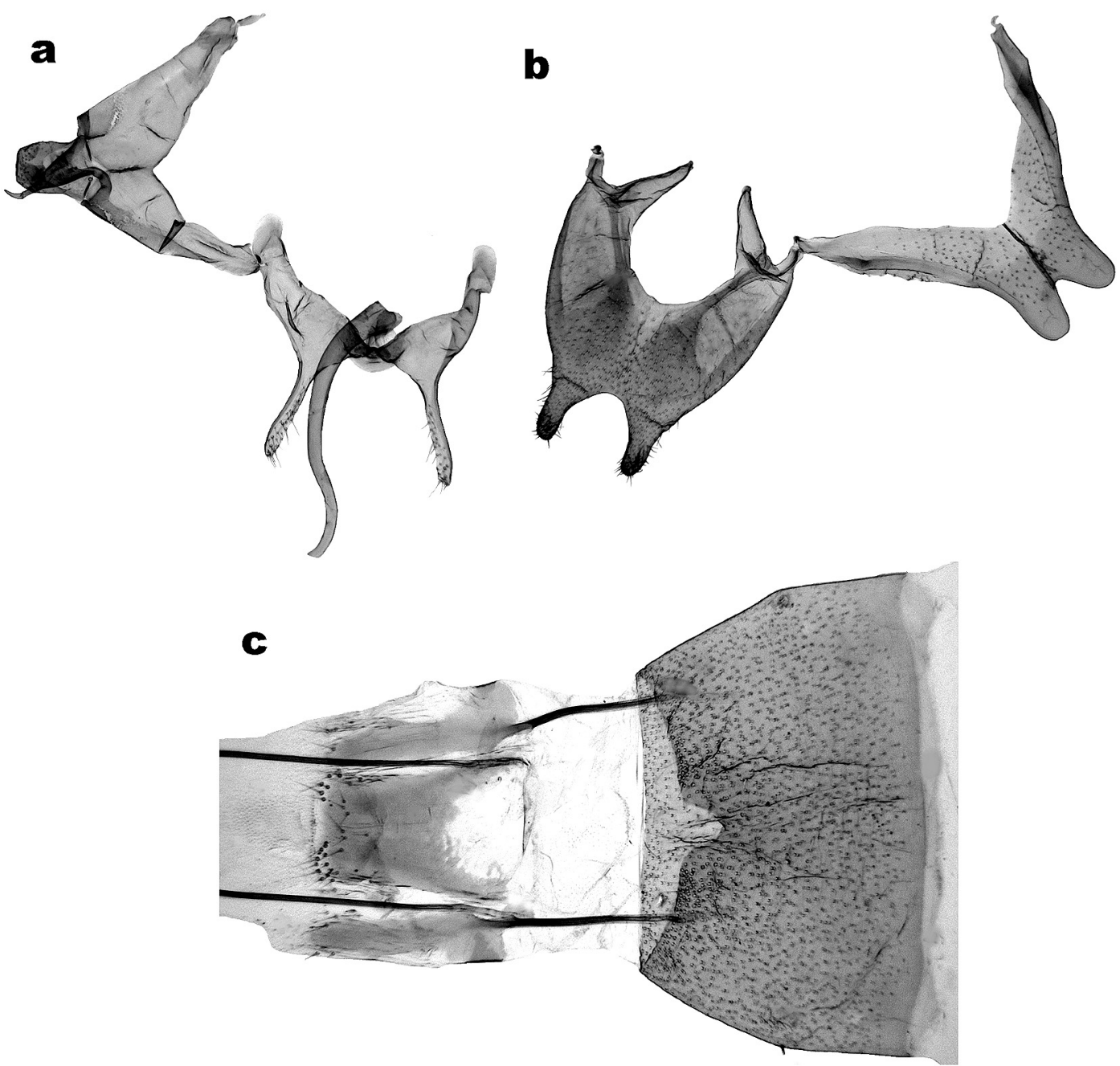

Fig. 8. - a. Male genitalia of Scythris pototskii (paratype). - b. Tergum VIII (right) and sternum VIII (left) of Scythris pototskii (paratype). - c. Female genitalia of Scythris pototskii (paratype).

physes anteriores $0.45 \times$ length of apophyses posteriores.

Bionomy. The specimens were collected by sweeping at daylight. The habitat is a dry, rocky steppe with sparse vegetation (Fig. 2). The immature stages are unknown.

Distribution. SE Kazakhstan.

Etymology. This species is dedicated to Mr. Aleksandr Pototski, an Estonian lepidopterist who collected half of the type series of the new taxon.

Remarks. S. pototskii belongs to the subfasciata species-group.
Acknowledgements. We thank Mr. Bengt Å. Bengtsson (Färjestaden, Sweden) for fruitful discussions concerning the present material and Dr. Tomasz Baran (Rzeszow, Poland) for useful comments on the manuscript, and Dr. Vladimir Kononenko (Vladivostok, Russia) and Mr. Kimmo Silvonen (Espoo, Finland) for their help in processing the photographs.

\section{References}

Bengtsson, B. A. 1997: Notes on interesting scythridids in the Zoological Museum, Helsinki, Finland (Lepidoptera, Scythrididae). — Entomologica Fennica 8: 89102.

Falkovitch, M. I. 1969: O pishchevykh svyazakh pustinnykh cheshuekrylykh (Lepid.) v srednei Azii. [About 
trophic relationships in Lepidoptera from steppe areas of Middle Asia]. In Doklady na dvatsat'pervom ezhegodnom chtenii pamyati N.A. Cholodkovskogo. - Akademiya Nauk SSSR. Vsesoyuznoe Entomologicheskoe Obshchestvo (1968): 53-88. [In Russian].

Falkovitch, M. I. 1972: Novye vidy roda Scythris Hb. (Lepidoptera, Scythrididae) iz sreznei Azii. [New species of the genus Scythris Hb. (Lepidoptera, Scythrididae) from Middle Asia]. - Novye vidy morskikh I nazemnykh bespozvonochnykh. Akademiya Nauk SSSR, Trudy Zoologicheskogo Instituta 52: 319-331. [In Russian].

Falkovitch, M. I. 1979: Novyi vidy roda Scythris Hbn. (Lepidoptera, Scythrididae) iz pustyni Kyzylkum. [A new species in the genus Scythris Hbn. From Kyzylkum desert area]. - Novye vidy naskomykh. Akademiya Nauk SSSR. Trudy Vsesoyuznogo Entomologicheskogo Obshchestva 62: 107-110. [In Russian].

Falkovitch, M. I. 1986: Cheshuekrylye (Lepidoptera) Ostantsovykh gor Kul'dzhuktau I podgornoi raviny (yugozapadnyi Kyzylkum). [Lepidoptera from Kuldzhuktau Mountain and submountain plain, south- west Kyzylkum)]. — Fauna Cheshuekrylykh (Lepidoptera) SSSR. Trudy Vsesoyuznogo Entomologicheskogo Obshchestva 67: 131-186. [In Russian].

Nupponen, K. 2003: Contribution to the scythridid fauna of southern Buryatia, with description of seven new species (Lepidoptera: Scythrididae). — Entomologica Fennica 14: 25-45.

Nupponen, K., Bengtsson, B. Å., Kaitila, J.-P., Nupponen, T., Junnilainen, J. \& Olschwang, W. 2000: The scythridid fauna of the southern Ural Mountains, with description of fourteen new species (Lepidoptera: Scythrididae). - Entomologica Fennica 11: 5-34.

Sachkov, S. A. 2000: New species of scythridid moths (Lepidoptera, Scythrididae) from the middle Volga River region. - Zoologicheskii Zhurnal 79(12): 1479-1484. [In Russian].

Sachkov, S. A. 2002: A new and a little-known species of Scythris Hübner, 1825 (Lepidoptera: Scythrididae) from Kazakhstan and the Middle Volga, and three species of Scythris newly synonymized. - Entomologist's Gazette 53: 259-264.

Sinev, S. Y. 1993: New and little-known species of the genus Scythris (Lepidoptera, Scythrididae) from Altai. Vestnik zoologii 2: 53-57. [In Russian]. 